\title{
Sensory Pollution from Bag Filters, Carbon Filters and Combinations
}

Bekö, Gabriel; Clausen, Geo; Weschler, Charles J.

Publication date:

2007

Document Version

Publisher's PDF, also known as Version of record

Link back to DTU Orbit

Citation (APA):

Bekö, G., Clausen, G., \& Weschler, C. J. (2007). Sensory Pollution from Bag Filters, Carbon Filters and Combinations. Abstract from Clima 2007 WellBeing Indoor Congress, Helsinki, Finland.

\section{General rights}

Copyright and moral rights for the publications made accessible in the public portal are retained by the authors and/or other copyright owners and it is a condition of accessing publications that users recognise and abide by the legal requirements associated with these rights.

- Users may download and print one copy of any publication from the public portal for the purpose of private study or research.

- You may not further distribute the material or use it for any profit-making activity or commercial gain

- You may freely distribute the URL identifying the publication in the public portal

If you believe that this document breaches copyright please contact us providing details, and we will remove access to the work immediately and investigate your claim. 


\title{
Sensory Pollution from Bag Filters, Carbon Filters and Combinations
}

\author{
Gabriel Bekö ${ }^{1,2}$, Geo Clausen ${ }^{1}$, Charles J. Weschler ${ }^{1,3}$ \\ ${ }^{1}$ International Centre for Indoor Environment and Energy, Dept. of Mechanical Engineering, \\ Technical University of Denmark, Lyngby, Denmark \\ ${ }^{2}$ Faculty of Civil Engineering, Slovak University of Technology, Bratislava, Slovakia \\ ${ }^{3}$ EOHSI (UMDNJ-RW Johnson Medical Schl \& Rutgers Univ.), Piscataway, NJ 08854 USA
}

Corresponding email: gb@mek.dtu.dk

\section{Introduction}

Used ventilation filters commonly emit sensory pollutants, which may negatively impact sick building syndrome symptoms and occupant performance. Organic compounds associated with the captured particles can chemically transform (e.g. be oxidized) and/or desorb to the airstream. Such processes are anticipated to contribute to the degradation of perceived air quality. The present experiment investigated the sensory pollution from different combinations of bag-type filters and activated carbon filters after several months of continuous operation.

\section{Methods}

Various combinations of new filters were placed in eight units containing one or more filter housings of $60 \times 30 \mathrm{~cm}$ size and a fan. All units operated at the same outdoor location with a continuous airflow of $1300 \mathrm{~m}^{3} / \mathrm{h}$ for 5 months. The eight tested filter sets were:

1) Single EU7 glass fiber filter;

2) EU7 glass fiber filter protected by a EU4 prefilter, which was exchanged monthly;

3) EU7 glass fiber filter with an activated carbon (AC) filter upstream, to limit ozone initiated reactions on the surface of the EU7;

4) EU7 glass fiber filter with an AC filter downstream to remove organics desorbing from the EU7 filter surface;

5) EU7 glass fiber filter with AC filters both upstream and downstream;

6) EU7 pocket filter with carbon-filled fiberglass media (moderate amount of AC);

7) EU7 synthetic fiber cartridge filter with a larger amount of AC than \#6; and

8) Single EU5 glass fiber filter.

Thirty-two human subjects assessed the perceived air quality downstream of the 5month-used filters at $130 \mathrm{~m}^{3} / \mathrm{h}$ airflow indoors
( $\left.21^{\circ} \mathrm{C}, 25 \% \mathrm{RH}\right)$. They recorded their assessments using a continuous acceptability scale with a range of acceptability from -1 (clearly unacceptable) to +1 (clearly acceptable). A set of brand-new filters, identical to the used ones, was assessed in an identical manner.

\section{Results}

Table 1 shows the results of the sensory assessments for the used filter sets and the average acceptability of air (ACC) downstream of the same filter sets consisting of new filters.

Table 1. Mean acceptability of air and the 95\% confidence intervals.

\begin{tabular}{|c|c|}
\hline Filter set No. & Mean ACC \pm 95\%CI \\
\hline 1-used & $-0.43 \pm 0.14$ \\
\hline 2-used & $-0.25 \pm 0.13$ \\
\hline 3-used & $-0.18 \pm 0.14$ \\
\hline 4-used & $0.34 \pm 0.16$ \\
\hline 5-used & $0.48 \pm 0.11$ \\
\hline 6-used & $0.33 \pm 0.16$ \\
\hline 7-used & $0.10 \pm 0.17$ \\
\hline 8-used & $-0.07 \pm 0.15$ \\
\hline All-new (aver.) & $0.45 \pm 0.12$ \\
\hline
\end{tabular}

See Methods section for filter numbering details.

\section{Conclusions}

The results indicate that activated carbon filters downstream of particle filters in HVAC systems can meaningfully improve indoor air quality as the upstream filters accumulate captured particles. In comparison with commonly used fibrous pocket filters, those with carbon-filled fiberglass media could reduce the degradation of air quality that occurs with increasing filter service and, at the same time, remove a significant fraction of ozone from the supply air. Further experiments are warranted to confirm these striking results, especially with filter sets 4, 5 and 6. 